\title{
Removal of Reactive Orange 16 Dye from Aqueous Solution by Using Modified Kenaf Core Fiber
}

\author{
Maytham Kadhim Obaid, ${ }^{1,2}$ Luqman Chuah Abdullah,, ${ }^{1}$ and Intidhar Jabir Idan ${ }^{1,2}$ \\ ${ }^{1}$ Department of Chemical and Environmental Engineering, Faculty of Engineering, Universiti Putra Malaysia, \\ 43400 Serdang, Selangor, Malaysia \\ ${ }^{2}$ Department of Environmental Engineering, Faculty of Engineering, University of Babylon, Hilla, Babylon, Iraq
}

Correspondence should be addressed to Maytham Kadhim Obaid; abuthar210@gmail.com

Received 23 March 2016; Revised 4 April 2016; Accepted 28 April 2016

Academic Editor: Wenshan Guo

Copyright (c) 2016 Maytham Kadhim Obaid et al. This is an open access article distributed under the Creative Commons Attribution License, which permits unrestricted use, distribution, and reproduction in any medium, provided the original work is properly cited.

Evaluated removal of reactive orange 16 (RO16) dye from aqueous solution was studied in batch mode by using kenaf core fiber as low-cost adsorbents. In this attempt, kenaf core fiber with size $0.25-1 \mathrm{~mm}$ was treated by using (3-chloro-2-hydroxypropyl) trimethylammonium chloride (CHMAC) as quaternization agent. Then effective parameters include adsorbent dose, $\mathrm{pH}$, and contact time and initial dye concentration on adsorption by modified kenaf core fiber was investigated. In addition, isotherms and kinetics adsorption studies were estimated for determination of the equilibrium adsorption capacity and reactions dynamics, respectively. Results showed that the best dose of MKCF was $0.1 \mathrm{~g} / 100 \mathrm{~mL}$, the maximum removal of $\mathrm{RO} 16 \mathrm{was} 97.25$ at $30^{\circ} \mathrm{C}$, $\mathrm{pH}=$ 6.5, and agitation speed was $150 \mathrm{rpm}$. The results also showed that the equilibrium data were represented by Freundlich isotherm with correlation coefficients $R^{2}=0.9924$, and the kinetic study followed the pseudo-second-order kinetic model with correlation coefficients $R^{2}=0.9997$ for $C_{o}=100 \mathrm{mg} / \mathrm{L}$. Furthermore, the maximum adsorption capacity was $416.86 \mathrm{mg} / \mathrm{g}$. Adsorption through kenaf was found to be very effective for the removal of the RO16 dye.

\section{Introduction}

Effluents from the textile industry and many other industries contain various kinds of synthetic dyestuffs, and there has been growing interest in regard to decolonization of these effluents in the last few years [1]. Removing the color from wastewater is often more significant than other colorless organic substances because the presence of small amounts of dyes (below $1 \mathrm{ppm}$ ) is distinctly visible and influences the water environment considerably [2].

Most dyes are nonbiodegradable in nature, which is stable to light and oxidation. Therefore, the degradation of dyes in wastewater either traditional biological process or chemical process has not been very effective [3].

Many conventional methods have been used for removal of dye pollution from industrial wastewaters, including chemical and physical methods. But these methods are often ineffective in the removal of dyes, highly costly, and less adaptable to dye-loaded wastewaters [4]. Adsorption process has been a choice because it allows the removal of different types of dyes and the method is simple, effective, and easy operation [5]. The significant economic cost has increased the concentration of researchers in search of less costly materials and economic as adsorbents for application in wastewater treatment [6-8]. Agricultural products from renewable resource which are less expensive and biodegradable and environmentally friendly [9-12] have been used as an alternative to removing dyes from wastewater [13-20]. But to increase the usability and make agricultural by-products more efficient and reduce the numerous problems when they are directly used, they lower adsorption capacity for anionic pollutants $[21,22]$. It is necessary to treat or modify these materials prior to application in adsorption processes [2326]. Table 1 shows some of the modified agricultural solid wastes.

One of the important agricultural materials is kenaf (Hibiscus cannabinus), which is an ancient crop and has a long history of being planted and used by human beings. It 
TABLE 1: Previous studies of uptake of dyes using adsorbents based on agricultural solid wastes.

\begin{tabular}{|c|c|c|c|}
\hline Adsorbents & Dyes & $q_{\max }(\mathrm{mg} / \mathrm{g})$ & References \\
\hline Almond shell activated carbon at $750^{\circ} \mathrm{C}$ & Methylene blue & 1.33 & [37] \\
\hline Peanut hull & Sunset yellow & 13.99 & {$[38]$} \\
\hline Waste apricot activated carbon & Methylene blue & 102.04 & {$[39]$} \\
\hline Treated coconut male flowers carbons & Crystal violet & 60.42 & {$[40]$} \\
\hline Jute fiber & Eosin yellow & 31.489 & {$[41]$} \\
\hline Wheat bran & Malachite green & 66.57 & {$[33]$} \\
\hline Coconut coir pith & Direct Red 12B & 76.3 & {$[42]$} \\
\hline Rice husk & Indigo carmine & 29.2799 & {$[43]$} \\
\hline Neem sawdust & Malachite green & 4.35 & {$[44]$} \\
\hline Thespesia populnea pods activated carbon & Orange $\mathrm{G}$ dye & 9.129 & {$[45]$} \\
\hline Kenaf fiber char & Methylene blue & 18.18 & {$[46]$} \\
\hline Quaternized flax shive & Reactive red 228 & 190.0 & {$[47]$} \\
\hline Modified kenaf core fibers & Reactive orange & 416.86 & This work \\
\hline
\end{tabular}

is one of the best alternative crops that provide a good source of cellulose. Due to its environmental and biodegradability compatibility, the usage of kenaf has increased [27]. Malaysia is in the process of developing kenaf cultivation and processing. Nevertheless, it was only in 2010 that Malaysian government seriously accepted kenaf as the Malaysian seventh commodity, through the setting up of the National Kenaf and Tobacco Board, 2013. The production in Malaysia is estimated at 3,000 tons to 10,000 tons of kenaf fiber annually. Kenaf is annually cultivated from its seeds for the fibers. In this paper, the kenaf was modified using $\mathrm{NaOH}$ (as shown in the next paragraphs). In this research, the objective is to evaluate the adsorption potential of modified kenaf for the removal of anionic dyes. The effects of different factors on the adsorption such as $\mathrm{pH}$, contact time, and initial dye concentration are studied in batch method. The kinetic data and equilibrium of the adsorption are processed to comprehend the adsorption.

\section{Materials and Methods}

2.1. Preparation of Modified Kenaf Core Fibers (MKCF). The kenaf fibers (core chips) were ground using pulverization, then stainless steel sieves with sizes $1 \mathrm{~mm}$ and $0.25 \mathrm{~mm}$ were used to obtain kenaf core fibers in size range from $0.25 \mathrm{~mm}$ to $1 \mathrm{~mm}$.

Kenaf core fibers modification consists of alkali treatment; this kind of treatment is very important to make many pores on the kenaf surface-wide. There are three steps to modified kenaf core fibers which are cleaning, mercerization, and quaternization. For a cleaning process, the kenaf core fibers were washed with distilled water several times and then dried in the oven at a temperature of at $50^{\circ} \mathrm{C}$ for 24 hours. Then the clean kenaf core fibers were mercerized by soaking them in $20 \%$ weight of $\mathrm{NaOH}$ solution for 24 hours. It is important to let kenaf fibers swell enough. Mercerization is a treatment of fibers with an alkali. The alkali causes the fibers walls to swell and become active, thus increasing in strength, luster, and absorbency. Then mercerized kenaf fibers were rinsed with distilled water and dried at $50^{\circ} \mathrm{C}$. For quaternization process, each gram of kenaf core fibers was
TABLE 2: General properties of reactive orange 16.

\begin{tabular}{lc}
\hline Name of the commercial dye & Reactive orange 16 \\
$\lambda_{\max }(\mathrm{nm})$ & $493 \mathrm{~nm}$ \\
Molecular weight $(\mathrm{g} / \mathrm{mol})$ & 617.54 \\
Dye content & $\geq 70 \%$ \\
Chemical formula & $\mathrm{C}_{20} \mathrm{H}_{17} \mathrm{~N}_{3} \mathrm{Na}_{2} \mathrm{O}_{11} \mathrm{~S}_{3}$ \\
\hline
\end{tabular}

reacted with a solution consisting of $1.5 \mathrm{~g}: 6.67 \mathrm{~mL}: 2.5 \mathrm{~mL}$ of $\mathrm{NaOH}$, 3-chloro-2-hydroxypropyltrimethyl ammonium chloride (CHMAC), and distilled water, respectively. Hence, the solution added to each gram of kenaf core fibers contained $37 \mathrm{mmol}$ of $\mathrm{NaOH}$ and $62.5 \mathrm{mmol}$ of (3-chloro-2hydroxypropyl) trimethyl ammonium chloride (CHMAC). The mixture was kept in sealed container at room temperature. After 24 hours, $0.2 \%$ acetic acid solution was added to the blend to stop the reaction followed by washing with distilled water until $\mathrm{pH}$ (7-8) which is a neutral condition. Then modified kenaf core fibers were dried at $50^{\circ} \mathrm{C}$ and stored in a dry place.

2.2. Preparation of Stock Solution. The stock solution was prepared by dissolving (1) gram from the dye in $1 \mathrm{~L}$ of distilled water in the volumetric flask. The mixture was kept in storage bottle with screw cap at room temperature for 24 hours to make sure that the stock solution becomes homogeneous and keeps away from light to reduce the external influences. The experimental solution was prepared by diluting the specified volume of the stock solution to get the desired concentration. The general characteristics of reactive orange 16 dye are shown in Table 2. In this study, the decolorization of the aqueous solution was studied in batch mode.

For absorbance measurements, a spectrophotometer UV1800 (SHMADZU) was employed. The maximum wavelength for RO16 dye is $493 \mathrm{~nm}$. Concentrations during experimental work were determined from a standard calibration curve. The dye solution was filtered through filter paper to separate the adsorbent prior to running the UV spectrophotometer analysis. The amount of adsorbent adsorbed at equilibrium 


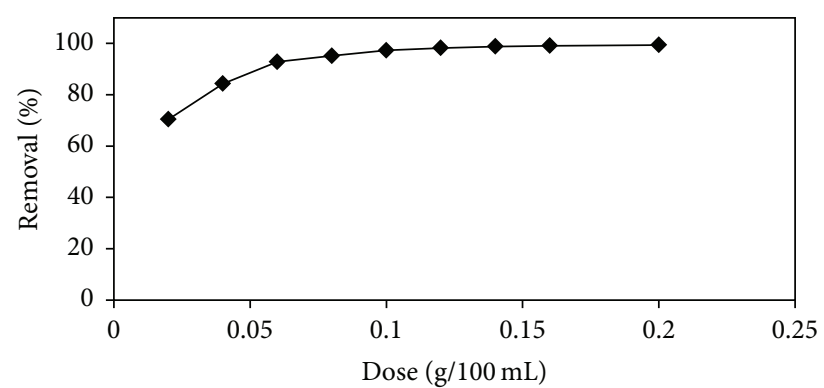

FIgURE 1: Effect of MKCF dosage on RO16 removal.

condition, $q_{e}(\mathrm{mg} / \mathrm{g})$, and the percentage of removal efficiency $(R \%)$ were calculated using (1) and (2), respectively. One has

$$
\begin{gathered}
q_{e}=\left(C_{o}-C_{e}\right) * \frac{V}{W} \\
R(\%)=\left(C_{o}-\frac{C_{e}}{C_{o}}\right) * 100,
\end{gathered}
$$

where $C_{o}$ and $C_{e}$ are initial dye concentrations and final dye concentrations $(\mathrm{mg} / \mathrm{L})$, respectively, $V$ is the volume of solution (L), and $W$ is the weight of MKCF (g).

\section{Results and Discussion}

3.1. Dosage Effect. The effect of adsorbent dose was studied in a batch method using $250 \mathrm{~mL}$ Erlenmeyer flasks. In each flask, the volume of dye was $100 \mathrm{~mL}$. All flasks were sealed properly using aluminum foil to prevent leakage and evaporation. The shaking rate was set at $150 \mathrm{rpm}$ at the temperature of $30^{\circ} \mathrm{C}$, with the contact time of 24 hours. The initial dye concentration of RO16 in this solution was $100 \mathrm{mg} / \mathrm{L}$ and the dosages of MKCF were $0.02,0.04,0.06,0.08,0.1,0.12,0.14$, 0.16 , and $0.2 \mathrm{~g} / 100 \mathrm{~mL}$, respectively. Based on Figure 1, it was observed that the percentage of dye removal increased with respect to MKCF dosage until $1 \mathrm{~g} / \mathrm{L}$ and then further increase in MKCF dosage resulting in the constant percentage of dye removal due saturation point. MKCF could remove $97.25 \%$ for RO16 dye with a dosage of $1 \mathrm{~g} / \mathrm{L}$. Therefore, the adsorbent dosage was optimized at $1 \mathrm{~g} / \mathrm{L}$ of MKCF.

3.2. $p H$ Effect. $\mathrm{pH}$ has the significant impact on absorption process and affected absorption capacity, dye solubility [28], solution chemistry, and a surface of absorbent pore [29]. The effect of $\mathrm{pH}$ on the adsorption capability was investigated between $\mathrm{pH} 2.0$ and 12 at $30^{\circ} \mathrm{C}$ and the shaking rate was set at $150 \mathrm{rpm}$ (Figure 2). The percentage removal of RO16 increased from $95 \%$ to $98.12 \%$ with an increase of the $\mathrm{pH}$ from 2 to 8 . Adsorption rate did not vary significantly and the removal percentage was steady around $98 \%$. The authors attributed this behavior to the availability of a considerable number of active locations on the adsorbent surface and related the solute uptake to the active sites and also to the chemistry of the solute in the solution. The neutral $\mathrm{pH}$ system showed good adsorption behavior for the RO16 dye solution.

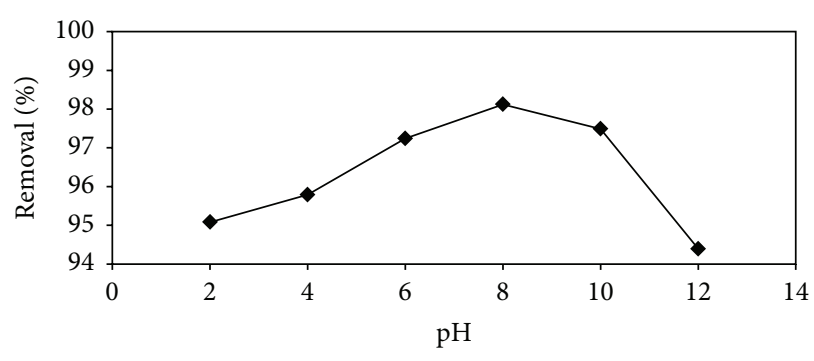

Figure 2: Effect of $\mathrm{pH}$ on $\mathrm{RO} 16$ removal.

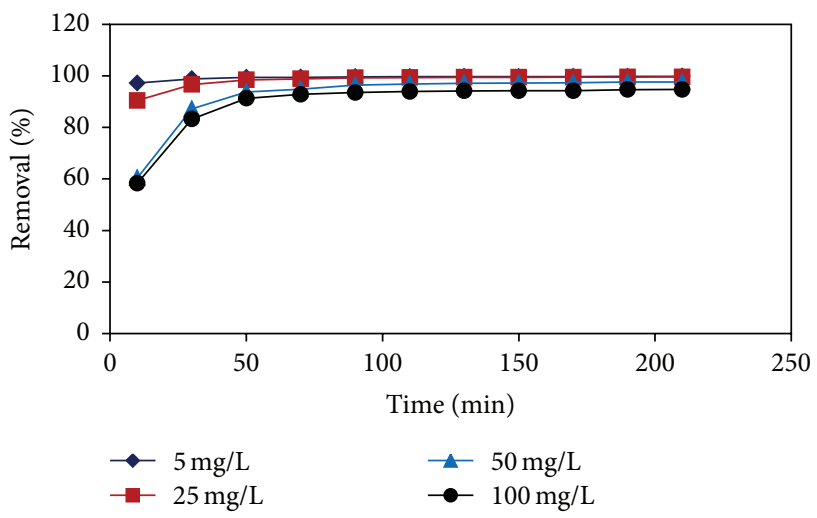

FIGURE 3: Effect of contact time on RO16 removal for different initial dye concentration.

3.3. Effects of Initial Dye Concentration and Contact Time. Equilibrium time is one of the important aspects in the design of water and wastewater treatment systems because it impacts the size of the reactor and thereby economizes the treatment plant [30].

The effect of contact time on the rate of removal of RO16 dye is shown in Figure 3. The percentage removal of dye increased with an increase in contact time and reached to equilibrium after $110 \mathrm{~min}$ for initial dye concentrations $(5,25$, 50 , and $100 \mathrm{mg} / \mathrm{L}$ ). The shaking rate was set at $150 \mathrm{rpm}, \mathrm{pH}$ 6.5 , and a temperature of $30^{\circ} \mathrm{C}$ used in this study.

\section{Adsorption Isotherm}

The equilibrium adsorption isotherm is one of the most important data to understand the mechanism of the adsorption systems. Several isotherm equations are available and two important isotherms are selected in this study, which are, namely, the Langmuir and Freundlich models.

An assumption has been made on Langmuir isotherm that adsorption on a homogenous surface containing site will occur with equal energy that is equally available for adsorption [31]. As Langmuir isotherm is monolayer isotherm, there is no transmigration of adsorbate on the surface plane [32]. The Langmuir equation can be described by the linearized form given by

$$
\frac{C_{e}}{q_{e}}=\frac{1}{b q_{\max }}+\frac{C_{e}}{q_{\max }}
$$


TABLE 3: Langmuir and Freundlich constants for adsorption of RO16 on MKCF.

\begin{tabular}{lccccccc}
\hline \multirow{2}{*}{ Name of dye } & \multicolumn{3}{c}{ Langmuir constants } & \multicolumn{3}{c}{ Freundlich constants } \\
& $q_{\max }(\mathrm{mg} / \mathrm{g})$ & $b(\mathrm{~L} / \mathrm{mg})$ & $R^{2}$ & $R_{\mathrm{L}}$ & $K_{\mathrm{F}}$ & $1 / n$ & $R^{2}$ \\
\hline RO16 & 416.686 & 0.1244 & 0.9088 & 0.0744 & 61.81 & 0.488 \\
\hline
\end{tabular}

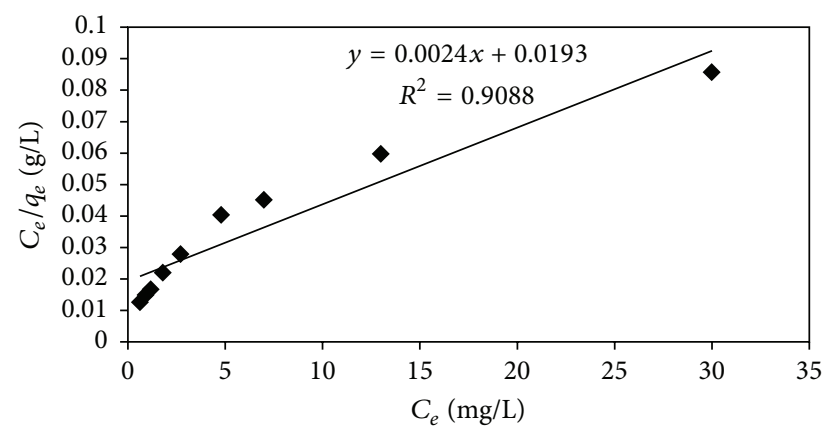

FIGURE 4: Langmuir adsorption isotherm for RO16 onto MKCF at $30^{\circ} \mathrm{C}$.

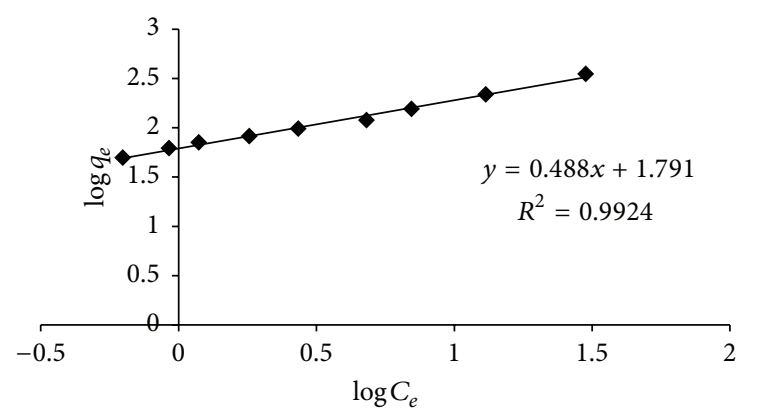

FIgURE 5: Freundlich adsorption isotherm for RO16 onto MKCF at $30^{\circ} \mathrm{C}$.

where $C_{e}$ is the equilibrium concentration $(\mathrm{mg} / \mathrm{L}), q_{e}$ is the equilibrium adsorption capacity $(\mathrm{mg} / \mathrm{g})$, and $b$ is the Langmuir constant or rate of adsorption $(\mathrm{L} / \mathrm{mg}$ or $\mathrm{L} / \mathrm{mole})$. A straight line was obtained when $C_{e} / q_{e}$ was plotted against $C_{e}$ and $q_{\max }$ and $b$ could be calculated from the slope and intercepts, respectively. The plotted data is shown in Figures 4 and 5. The essential feature of the Langmuir isotherm can be expressed by means of dimensionless constant separation factor which is calculated using

$$
R_{\mathrm{L}}=\frac{1}{\left(1+b \cdot C_{o}\right)}
$$

where $b$ denotes the Langmuir constant and $C_{o}$ denotes the initial dye concentration [33].

The Freundlich isotherm is an empirical equation used to describe heterogeneous systems. The Freundlich isotherm is given in logarithmic form as shown in (5) [34]. Consider

$$
\log q_{e}=\log K_{\mathrm{F}}+\left(\frac{1}{n}\right) \log C_{e},
$$

where $K_{\mathrm{F}}$ is the Freundlich constant and $n$ is the adsorption intensity. $1 / n$ is the empirical parameter that is related to

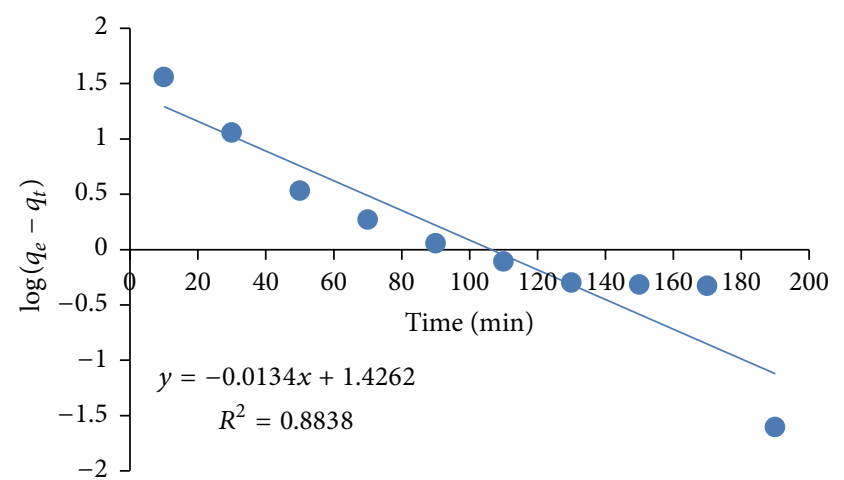

FIGURE 6: Kinetic study of adsorption of RO16 on MKCF by using pseudo-first-order kinetic model $\left(C_{o}=100 \mathrm{mg} / \mathrm{L}\right)$.

the adsorption intensity and this indicated whether the adsorption is favorable or not [35]. The values of $K_{\mathrm{F}}$ and $n$ can be calculated directly, from the slope and intercept that were obtained from the straight line when $\log q_{e}$ was plotted against $\log C_{e}$ (Figure 5).

Langmuir and Freundlich constants and correlation coefficients were listed in Table 3. From the table, it can be shown that the values of $q_{\max }$ are $416.686 \mathrm{mg} / \mathrm{g}$ for RO16. The correlation coefficients $\left(R^{2}\right)$ were found to be 0.9088 and 0.9924 for Langmuir and Freundlich isotherm, respectively. This confirmed that the Freundlich isotherm represented the adsorption of RO16 on MKCF. It can be concluded that the adsorption process for RO16 is heterogeneous.

\section{Kinetics Study}

Adsorption kinetics can measure the efficiency of adsorption process by several applications of kinetic modeling. To evaluate the rate of adsorption of modifying kenaf core fiber, the data in Figure 4 were used with pseudo-first-order and pseudo-second-order kinetic models. The formula of pseudofirst-order equation is shown in (6) [36]. Consider

$$
\log \left(q_{e}-q_{t}\right)=\log q_{e}-\left(\frac{K_{1}}{2.303}\right) * t
$$

The symbol $q_{e}$ indicates the amount of MKCF adsorbed (mg/g) at equilibrium, while $q_{t}$ means the amount of MKCF adsorbed at a time ( $\mathrm{min})$ and $K_{1}$ is the rate constant of adsorption process of the pseudo-first-order $\left(\mathrm{min}^{-1}\right)$. The values of $K_{1}$ and $q_{e \text { cal }}$ were calculated from the slopes and intercepts, respectively, of the plots of $\log \left(q_{e}-q_{t}\right)$ versus $t$ (Figure 6) and are presented in Table 4 . The calculated $q_{e}$ values obtained from this kinetic model did not satisfy the 
TABLE 4: Parameters and correlation coefficient $\left(R^{2}\right)$ of pseudo-first- and pseudo-second-order kinetic model for adsorption of RO16 by MKCF.

\begin{tabular}{lcccccc}
\hline \multirow{2}{*}{ Name of dye } & \multirow{2}{*}{$q_{e \exp }(\mathrm{mg} / \mathrm{g})$} & \multicolumn{2}{c}{ Pseudo-first-order kinetic model } & \multicolumn{4}{c}{ Pseudo-second-order kinetic model } \\
& & $q_{e_{\mathrm{cal}}}$ & $K_{1}$ & $R^{2}$ & $q_{e \text { cal }}$ & $K_{2}$ \\
\hline RO16 & 94.73 & 26.7 & 0.0309 & 0.8838 & 97.087 & 0.0000129 \\
\hline
\end{tabular}

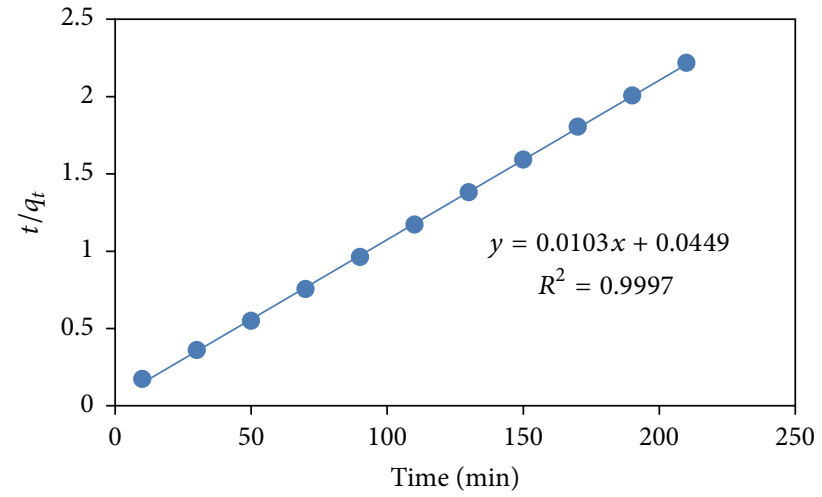

FIgURE 7: Kinetic study for adsorption of RO16 on MKCF by using pseudo-second-order kinetic model $\left(C_{o}=100 \mathrm{mg} / \mathrm{L}\right)$.

experimental one. Therefore, the adsorption process did not follow the pseudo-first-order model.

Pseudo-second-order model (7) had been achieved by plotting $t / q_{t}$ versus time $(t)$ [24]. The values of $K_{2}$ and calculated $q_{\mathrm{cal}}$ can be determined from the slope and intercept of the straight line, respectively, as shown in Figure 7. One has

$$
\frac{t}{q_{t}}=\frac{1}{\left(K_{2} * q_{e}^{2}\right)}+\left(\frac{1}{q_{e}}\right) * t .
$$

The correlation coefficient value for pseudo-second-order $\left(R^{2}\right)$ was 0.9924 , which indicates that kinetic adsorption fitted well with pseudo-second-order model. Closer values between calculated adsorption capacities $\left(q_{e_{\text {cal }}}\right)$ and the experimental adsorption capacities $\left(q_{e \text { exp }}\right)$ were also observed.

\section{Conclusion}

Until this moment, research is still standing at the low material cost and high ability removal; through qualitative study, we conclude that MKCF has a good ability to remove dye from aqueous solutions compared with other materials, and environmentally friendly. Moreover, MKCF can be used as alternatives to activated carbons reported in earlier studies and there are no secondary harmful effects from MKCF after removal dyes. In this research, RO16 dye was used and the maximum percentage removal was $97.24 \%$; it is a high percentage removal compared with other materials studied in other researches. The maximum adsorption capacity was $416.86 \mathrm{mg} / \mathrm{g}$; it is a good adsorption capacity for economic cost. The equilibrium data were analyzed using Langmuir and Freundlich isotherms. The characteristic parameters for each isotherm and related correlation coefficients were determined from graphs of their linear equations. Both Langmuir and Freundlich isotherms were demonstrated to provide a meaningful correlation for the adsorption of reactive dye, respectively.

\section{Competing Interests}

The authors declare that they have no competing interests.

\section{References}

[1] V. K. Gupta, I. Ali, T. A. Saleh, A. Nayak, and S. Agarwal, "Chemical treatment technologies for waste-water recycling-an overview," RSC Advances, vol. 2, no. 16, pp. 6380-6388, 2012.

[2] N. Daneshvar, D. Salari, and A. R. Khataee, "Photocatalytic degradation of azo dye acid red 14 in water: investigation of the effect of operational parameters," Journal of Photochemistry and Photobiology A: Chemistry, vol. 157, no. 1, pp. 111-116, 2003.

[3] H. Métivier-Pignon, C. Faur-Brasquet, and P. Le Cloirec, "Adsorption of dyes onto activated carbon cloths: approach of adsorption mechanisms and coupling of ACC with ultrafiltration to treat coloured wastewaters," Separation and Purification Technology, vol. 31, no. 1, pp. 3-11, 2003.

[4] A. Srinivasan and T. Viraraghavan, "Decolorization of dye wastewaters by biosorbents: a review," Journal of Environmental Management, vol. 91, no. 10, pp. 1915-1929, 2010.

[5] V. K. Gupta and Suhas, "Application of low-cost adsorbents for dye removal-a review," Journal of Environmental Management, vol. 90, no. 8, pp. 2313-2342, 2009.

[6] G. Crini, "Non-conventional low-cost adsorbents for dye removal: a review," Bioresource Technology, vol. 97, no. 9, pp. 10611085, 2006.

[7] M. ud Din, H. N. Bhatti, M. Yasir, and A. Ashraf, "Direct dye biosorption by immobilized barley husk," Desalination and Water Treatment, vol. 57, no. 20, pp. 9263-9271, 2016.

[8] V. K. Gupta, B. Gupta, A. Rastogi, S. Agarwal, and A. Nayak, "A comparative investigation on adsorption performances of mesoporous activated carbon prepared from waste rubber tire and activated carbon for a hazardous azo dye-Acid Blue 113," Journal of Hazardous Materials, vol. 186, no. 1, pp. 891-901, 2011.

[9] V. K. Gupta and A. Nayak, "Cadmium removal and recovery from aqueous solutions by novel adsorbents prepared from orange peel and $\mathrm{Fe}_{2} \mathrm{O}_{3}$ nanoparticles," Chemical Engineering Journal, vol. 180, pp. 81-90, 2012.

[10] T. G. Chuah, A. Jumasiah, I. Azni, S. Katayon, and S. Y. Thomas Choong, "Rice husk as a potentially low-cost biosorbent for heavy metal and dye removal: an overview," Desalination, vol. 175, no. 3, pp. 305-316, 2005.

[11] H. D. Doan, A. Lohi, V. B. H. Dang, and T. Dang-Vu, "Removal of $\mathrm{Zn}^{+2}$ and $\mathrm{Ni}^{+2}$ by adsorption in a fixed bed of wheat straw," Process Safety and Environmental Protection, vol. 86, no. 4, pp. 259-267, 2008.

[12] H. N. Bhatti and S. Nausheen, "Equilibrium and kinetic modeling for the removal of Turquoise Blue PG dye from aqueous 
solution by a low-cost agro waste," Desalination and Water Treatment, vol. 55, no. 7, pp. 1934-1944, 2015.

[13] V. K. Gupta, R. Jain, and S. Varshney, "Removal of Reactofix golden yellow 3 RFN from aqueous solution using wheat huskan agricultural waste," Journal of Hazardous Materials, vol. 142, no. 1-2, pp. 443-448, 2007.

[14] R. Han, P. Han, Z. Cai, Z. Zhao, and M. Tang, "Kinetics and isotherms of neutral red adsorption on peanut husk," Journal of Environmental Sciences, vol. 20, no. 9, pp. 1035-1041, 2008.

[15] I.-U. Haq, H. N. Bhatti, and M. Asgher, "Removal of solar red BA textile dye from aqueous solution by low cost barley husk: equilibrium, kinetic and thermodynamic study," Canadian Journal of Chemical Engineering, vol. 89, no. 3, pp. 593-600, 2011.

[16] A. Mittal, D. Kaur, A. Malviya, J. Mittal, and V. K. Gupta, "Adsorption studies on the removal of coloring agent phenol red from wastewater using waste materials as adsorbents," Journal of Colloid and Interface Science, vol. 337, no. 2, pp. 345-354, 2009.

[17] J. Mittal, V. Thakur, and A. Mittal, "Batch removal of hazardous azo dye Bismark Brown R using waste material hen feather," Ecological Engineering, vol. 60, pp. 249-253, 2013.

[18] W. Zou, P. Han, Y. Li, X. Liu, X. He, and R. Han, "Equilibrium, kinetic and mechanism study for the adsorption of neutral red onto rice husk," Desalination and Water Treatment, vol. 12, no. 1-3, pp. 210-218, 2009.

[19] S. Noreen, H. N. Bhatti, S. Nausheen, S. Sadaf, and M. Ashfaq, "Batch and fixed bed adsorption study for the removal of Drimarine Black CL-B dye from aqueous solution using a lignocellulosic waste: a cost affective adsorbent," Industrial Crops and Products, vol. 50, pp. 568-579, 2013.

[20] V. K. Gupta, S. Agarwal, and T. A. Saleh, "Synthesis and characterization of alumina-coated carbon nanotubes and their application for lead removal," Journal of Hazardous Materials, vol. 185, no. 1, pp. 17-23, 2011.

[21] W. S. Wan Ngah and M. A. K. M. Hanafiah, "Removal of heavy metal ions from wastewater by chemically modified plant wastes as adsorbents: a review," Bioresource Technology, vol. 99, no. 10, pp. 3935-3948, 2008.

[22] R. P. Han, L. J. Zhang, C. Song, M. M. Zhang, H. M. Zhu, and L. J. Zhang, "Characterization of modified wheat straw, kinetic and equilibrium study about copper ion and methylene blue adsorption in batch mode," Carbohydrate Polymers, vol. 79, no. 4, pp. 1140-1149, 2010.

[23] S. Chakraborty, S. Chowdhury, and P. Das Saha, "Adsorption of crystal Violet from aqueous solution onto $\mathrm{NaOH}$-modified rice husk," Carbohydrate Polymers, vol. 86, no. 4, pp. 1533-1541, 2011.

[24] Z. Wang, P. Han, Y. Jiao, D. Ma, C. Dou, and R. Han, "Adsorption of congo red using ethylenediamine modified wheat straw," Desalination and Water Treatment, vol. 30, no. 1-3, pp. 195-206, 2011.

[25] X. F. Ren, X. N. Zhang, L. J. Zhang, and R. P. Han, "Biosorption of methylene blue by natural and chemical modified wheat straw in fixed-bed column," Desalination and Water Treatment, vol. 51, no. 22-24, pp. 4514-4523, 2013.

[26] S. Sadaf, H. N. Bhatti, S. Nausheen, and S. Noreen, "Potential use of low-cost lignocellulosic waste for the removal of direct violet 51 from aqueous solution: equilibrium and breakthrough studies," Archives of Environmental Contamination and Toxicology, vol. 66, no. 4, pp. 557-571, 2014.

[27] M. N. A. M. Taib, M. A. Jamaludin, and M. A. Kassim, "Flexural properties of bio-composite made from hydrothermally treated kenaf (Hibiscus cannabinus) fibres," Advanced Materials Research, vol. 535-537, pp. 2409-2412, 2012.
[28] C. F. Iscen, I. Kiran, and S. Ilhan, "Biosorption of Reactive Black 5 dye by Penicillium restrictum: the kinetic study, Journal of Hazardous Materials, vol. 143, no. 1-2, pp. 335-340, 2007.

[29] J. F. Osma, V. Saravia, J. L. Toca-Herrera, and S. R. Couto, "Sunflower seed shells: A novel and effective low-cost adsorbent for the removal of the diazo dye Reactive Black 5 from aqueous solutions," Journal of Hazardous Materials, vol. 147, no. 3, pp. 900-905, 2007.

[30] S. K. Swain, T. Patnaik, V. K. Singh, U. Jha, R. K. Patel, and R. K. Dey, "Kinetics, equilibrium and thermodynamic aspects of removal of fluoride from drinking water using meso-structured zirconium phosphate," Chemical Engineering Journal, vol. 171, no. 3, pp. 1218-1226, 2011.

[31] A. L. Srivastav, P. K. Singh, V. Srivastava, and Y. C. Sharma, "Application of a new adsorbent for fluoride removal from aqueous solutions," Journal of Hazardous Materials, vol. 263, part 2, pp. 342-352, 2013.

[32] N. Viswanathan and S. Meenakshi, "Enhanced fluoride sorption using La(III) incorporated carboxylated chitosan beads," Journal of Colloid and Interface Science, vol. 322, no. 2, pp. 375-383, 2008.

[33] X. S. Wang, Y. Zhou, Y. Jiang, and C. Sun, "The removal of basic dyes from aqueous solutions using agricultural by-products," Journal of Hazardous Materials, vol. 157, no. 2-3, pp. 374-385, 2008.

[34] T. W. Weber and R. K. Chakravorti, "Pore and solid diffusion models for fixed-bed adsorbers," AIChE Journal, vol. 20, no. 2, pp. 228-238, 1974.

[35] H. N. Bhatti and Y. Safaa, "Removal of anionic dyes by rice milling waste from synthetic effluents: Equilibrium and thermodynamic studies," Desalination and Water Treatment, vol. 48, no. 1-3, pp. 267-277, 2012.

[36] L. Chen, H.-X. Wu, T.-J. Wang, Y. Jin, Y. Zhang, and X.-M. Dou, "Granulation of Fe-Al-Ce nano-adsorbent for fluoride removal from drinking water by spray coating on sand in a fluidized bed," Powder Technology, vol. 193, no. 1, pp. 59-64, 2009.

[37] A. Aygün, S. Yenisoy-Karakaş, and I. Duman, "Production of granular activated carbon from fruit stones and nutshells and evaluation of their physical, chemical and adsorption properties," Microporous and Mesoporous Materials, vol. 66, no. 2-3, pp. 189-195, 2003.

[38] R. Gong, Y. Sun, J. Chen, H. Liu, and C. Yang, "Effect of chemical modification on dye adsorption capacity of peanut hull," Dyes and Pigments, vol. 67, no. 3, pp. 175-181, 2005.

[39] C. A. Başar, "Applicability of the various adsorption models of three dyes adsorption onto activated carbon prepared waste apricot," Journal of Hazardous Materials, vol. 135, no. 1-3, pp. 232-241, 2006.

[40] S. Senthilkumaar, P. Kalaamani, and C. V. Subburaam, "Liquid phase adsorption of Crystal violet onto activated carbons derived from male flowers of coconut tree," Journal of Hazardous Materials, vol. 136, no. 3, pp. 800-808, 2006.

[41] K. Porkodi and K. Vasanth Kumar, "Equilibrium, kinetics and mechanism modeling and simulation of basic and acid dyes sorption onto jute fiber carbon: eosin yellow, malachite green and crystal violet single component systems," Journal of Hazardous Materials, vol. 143, no. 1-2, pp. 311-327, 2007.

[42] M. V. Sureshkumar and C. Namasivayam, "Adsorption behavior of Direct Red 12B and Rhodamine B from water onto surfactantmodified coconut coir pith," Colloids and Surfaces A: Physicochemical and Engineering Aspects, vol. 317, no. 1-3, pp. 277-283, 2008. 
[43] U. R. Lakshmi, V. C. Srivastava, I. D. Mall, and D. H. Lataye, "Rice husk ash as an effective adsorbent: evaluation of adsorptive characteristics for Indigo Carmine dye," Journal of Environmental Management, vol. 90, no. 2, pp. 710-720, 2009.

[44] S. D. Khattri and M. K. Singh, "Removal of malachite green from dye wastewater using neem sawdust by adsorption," Journal of Hazardous Materials, vol. 167, no. 1-3, pp. 1089-1094, 2009.

[45] M. Arulkumar, P. Sathishkumar, and T. Palvannan, "Optimization of Orange $\mathrm{G}$ dye adsorption by activated carbon of Thespesia populnea pods using response surface methodology," Journal of Hazardous Materials, vol. 186, no. 1, pp. 827-834, 2011.

[46] D. K. Mahmoud, M. A. M. Salleh, W. A. W. A. Karim, A. Idris, and Z. Z. Abidin, "Batch adsorption of basic dye using acid treated kenaf fibre char: equilibrium, kinetic and thermodynamic studies," Chemical Engineering Journal, vol. 181-182, pp. 449-457, 2012.

[47] L. Wang and J. Li, "Adsorption of C.I. reactive Red 228 dye from aqueous solution by modified cellulose from flax shive: kinetics, equilibrium, and thermodynamics," Industrial Crops and Products, vol. 42, no. 1, pp. 153-158, 2013. 

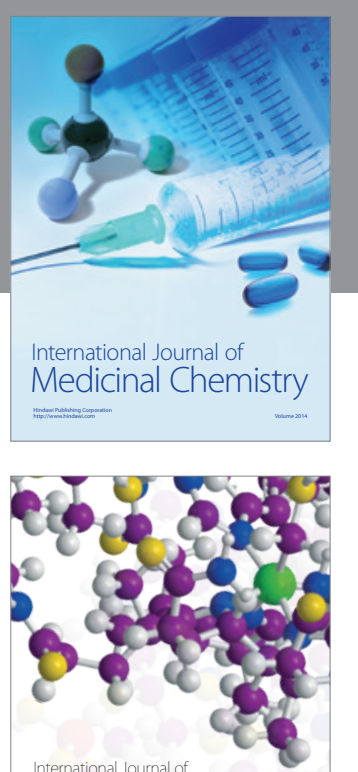

Carbohydrate Chemistry

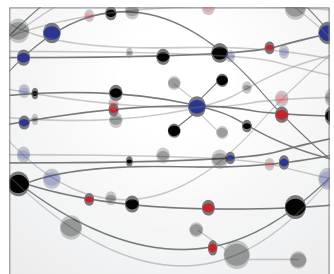

The Scientific World Journal
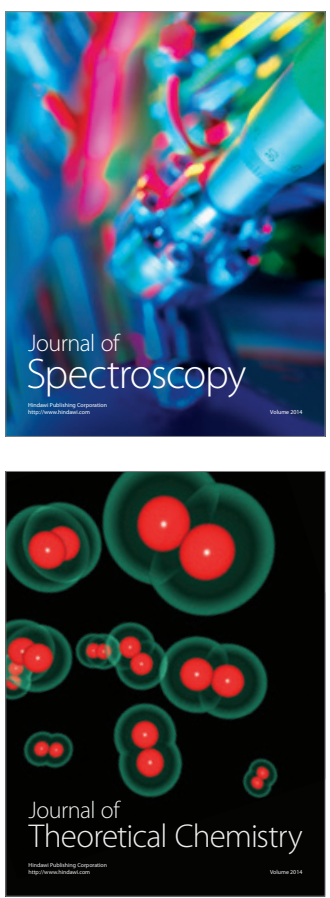
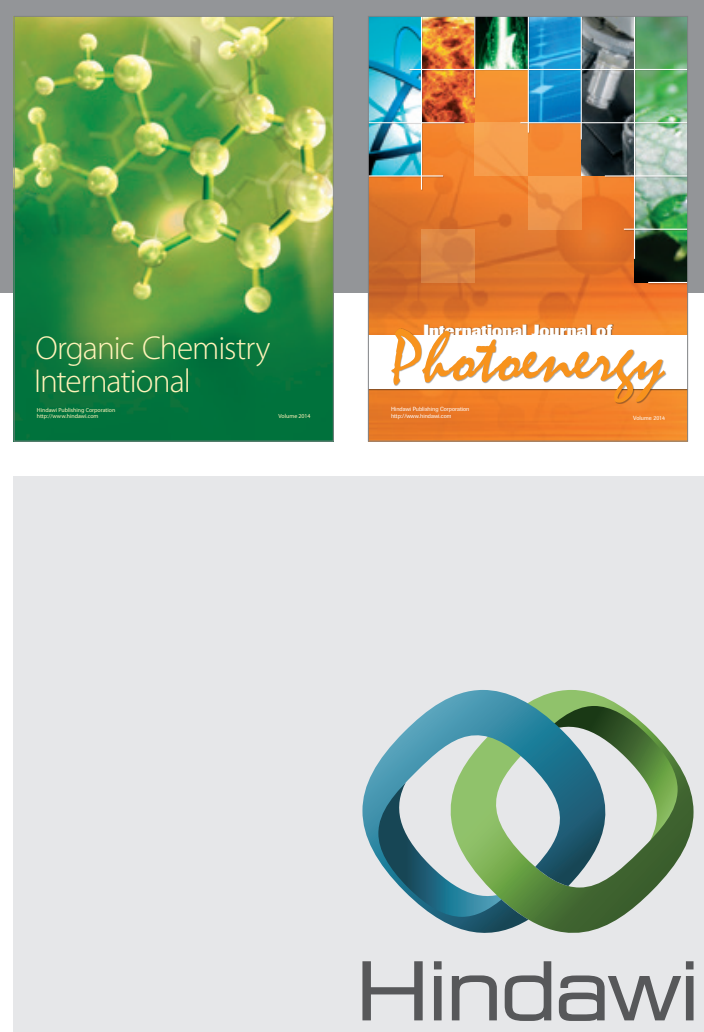

Submit your manuscripts at

http://www.hindawi.com

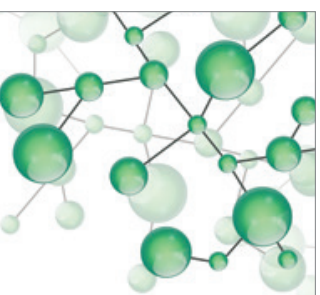

International Journal of

Inorganic Chemistry

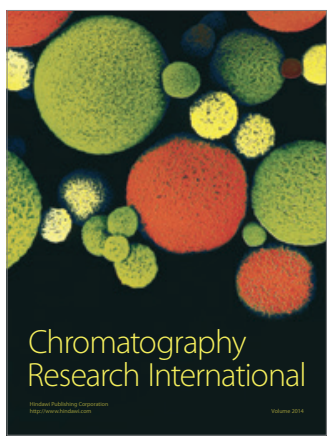

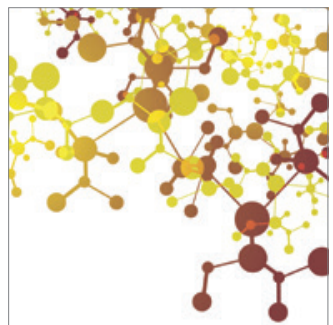

Applied Chemistry
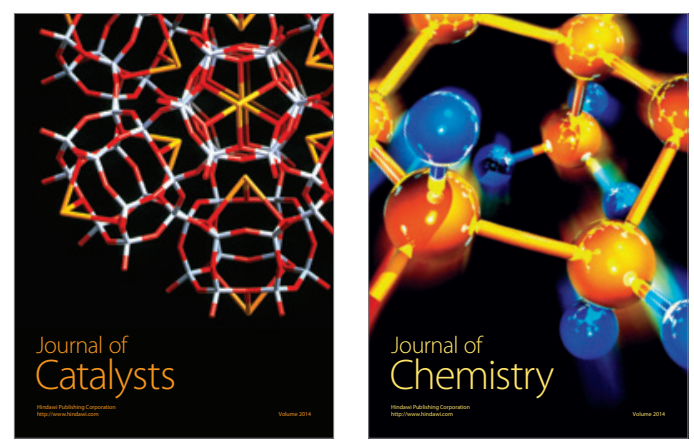
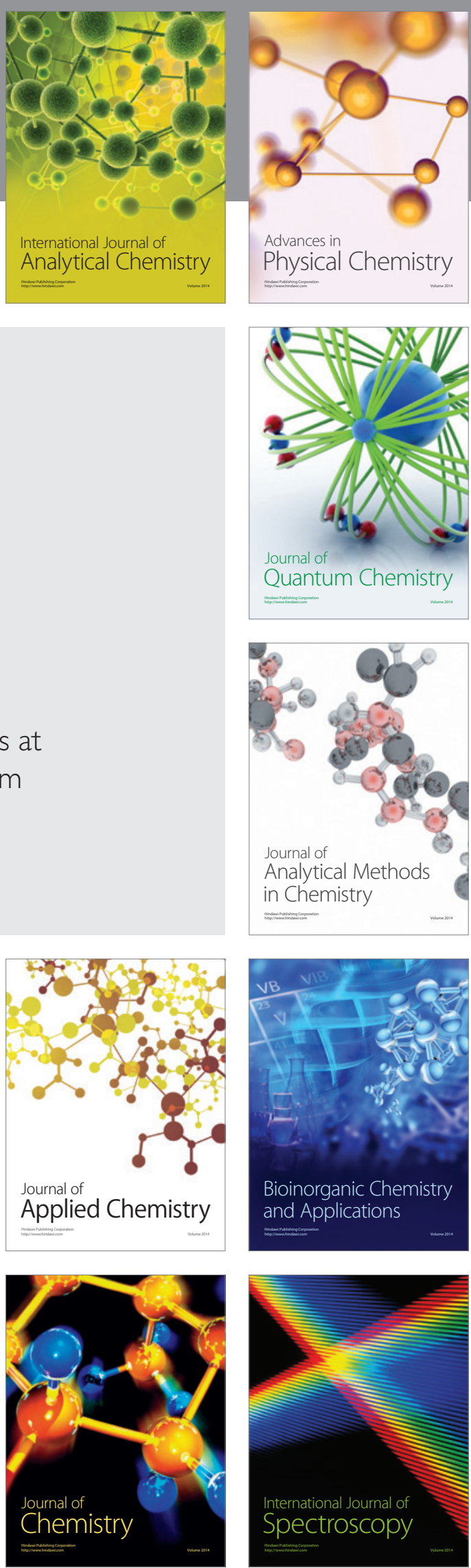